\title{
EFFECT OF MICROWAVE TREATMENT ON LONGITUDINAL AIR PERMEABILITY AND PRESERVATIVE UPTAKE CHARACTERISTICS OF CHIR PINE WOOD
}

\author{
Pawan Kumar Poonia $^{1, \$}$, Sanjeet Kumar Hom ${ }^{1}$, Kapil Sihag ${ }^{1}$, Sadhna Tripathi ${ }^{1}$
}

\begin{abstract}
Low permeability of many wood species due to their anatomical properties causes problems during timber drying as well as impregnating with preservatives and resins. Microwave (MW) treatment influences heartwood permeability and improves preservative uptake and distribution. In the present study, microwave treatment of chir pine (Pinus roxburghii) wood was done at $2,45 \mathrm{GHz}$ frequency at different level of intensity and radiation time. The gas permeability of chir pine wood was measured in an in-house built apparatus. Preservative uptake was tested using acid copper chromate (ACC) preservative by a dipping process. The effect of radiation intensity and time on preservative uptake and air permeability were studied. The results revealed remarkable increase in longitudinal wood air permeability and preservative uptake with the increase of intensity and time of treatment. The results indicate that this technology can be tested and applied on pilot scale for application in wood preservation industry.
\end{abstract}

Keywords: Acid Copper Chromate, dipping, impregnation, Pinus roxburghii, treatment time.

\section{INTRODUCTION}

Pinus roxburghii commonly known as chir pine. Its wood is moderately hard and has a density of $469 \mathrm{~kg} / \mathrm{m}^{3}$, and MOE $110,81000 \mathrm{~kg} / \mathrm{cm}^{2}$, MOR $494-744 \mathrm{~kg} / \mathrm{cm}^{2}$, compression parallel to grain 317 $\mathrm{kg} / \mathrm{cm}^{2}$ and shear $88,9 \mathrm{~kg} / \mathrm{cm}^{2}$ at $12 \%$ moisture content (Rajput et al. 1996). Although the species is readily treatable, there are efforts to reduce the treatment time for better acceptability. Panshin and de Zeeuw (1980) pointed out that in conifers the openings in the margo of the pit membranes are usually the limiting structures, and the low values of longitudinal permeability in softwoods points to the small sizes of these openings. Permeability is one of the key physical property that must be assessed to select a wood that readily accepts preservative and hence can be easily preserved (Fengel and Wegener 1984). Permeability of wood also affects processing time and product quality, both of which affect price (Hansmann et al. 2002).

Microwave (MW) radiation is an innovative method to increase the wood permeability and thus to improve the preservative penetration in the wood of various species (Torgovnikov and Vinden 2009, Dashti et al. 2012b). 
Torgovnikov and Vinden (2009) studied that green wood readily absorbs MW energy because of its high MC. When the microwave energy was applied to wood, the steam pressure generated within the wood cells ruptures the pit membranes and ray cells, allowing an easier fluid transfer. A several thousand-fold increase in wood permeability in the radial and longitudinal directions can be achieved (Vinden et al. 2010).

Xu et al. (2015) studied that the effect of microwave pre-treatment on the impregnation of poplar wood. The result showed that the improved transverse permeability of poplar wood that had received microwave pretreatment resulted in a positive influence on the amount of impregnation.

MW modification of wood structure can increase the wood permeability, the rate of drying in hardwoods, improve drying quality and even produce new composite products and open new opportunities for increasing timber durability by impregnation with preservatives.

In this study, microwave treatment was done to improve the air permeability and preservative uptake of chir pine wood.

\section{MATERIALS AND METHODS}

\section{Preparation of Samples}

Freshly felled logs of Pinus roxburghii Sarg. with $90 \mathrm{~cm}$ girth were procured from Forest Research Institute, Dehradun. Planks of 2,5 inches thickness with full log width and length were prepared. Planks were converted into longitudinal specimens of size $4 \mathrm{~cm}$ (Width) $\times 4 \mathrm{~cm}$ (Thickness) $\times 15 \mathrm{~cm}$ (Length). Straight grained and defect free specimens were submersed in fresh water to maintain green condition prior to MW treatment.

\section{Procedure}

MW Oven (model: 30SC3) with maximum output power $900 \mathrm{~W}$ at frequency $2450 \mathrm{MHz}$ was used for the experiment. Two time durations of $3 \mathrm{~min}$ (a) and $5 \mathrm{~min}$ (b) were used in the experiment for MW treatment at intensity of 95,57 (T-1); 111,50 (T-2) and 143,35W/cm ${ }^{2}$ (T-3). Controls (C-1) were maintained without MW treatment. Six replicates were prepared for each treatments and controls.

\section{Measurement of Longitudinal Air Permeability}

After MW treatment specimens were converted into cylindrical form of $20 \mathrm{~mm}$ diameter and $20 \mathrm{~mm}$ length and then specimens were subjected to measure the air permeability. The measurements of permeability to air in the longitudinal directions of chirpine were carried out in an in-house built apparatus (Figure 1). Air permeability was measured with atmospheric air. All the measurements were performed at room temperature and a pressure gauge coupled to a vacuum pump was used to measure the initial and final pressure during the assay. For the permeability measurement the samples were placed in the apparatus individually, a vacuum was applied, and then the air flow rate was measured, as shown in Figure 1. 


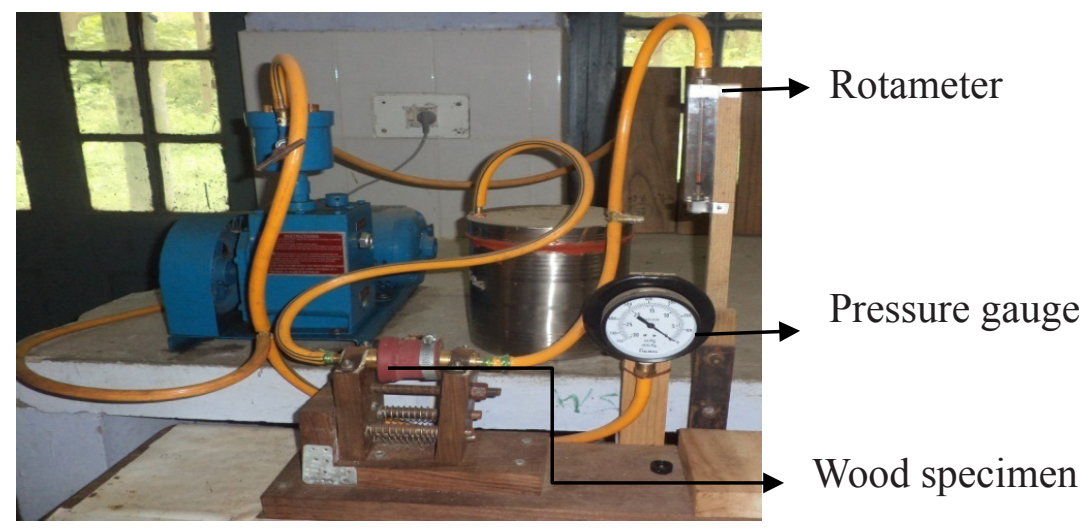

Figure 1. Air permeability measurement apparatus.

For permeability to gases, the apparatus consisted of one rotameter flow meter to measure the airflow rate in the ranges of 10 to $200 \mathrm{ml} / \mathrm{min}$. The atmospheric air flow rate was achieved by applying an initial absolute pressure of $275,79 \mathrm{kPa}$ for 2 minutes (until the float of rotameter became free from fluctuation) and then measuring the airflow rate on the rotameter. The permeability to gases was calculated by applying Darcy's law to the flow rates obtained as described above.

$$
K_{g}=\frac{q^{*} L^{*} P^{*} \eta}{A^{*} \Delta P^{*} \bar{P}}
$$

Where, $\mathrm{K}_{\mathrm{o}}$ is specific permeability coefficient with unit as Darcy; $\mathrm{q}$ is volumetric flow rate $\left(\mathrm{cm}^{3} /\right.$ $\mathrm{sec}) ; \mathrm{L}$ is the length of porous medium $(\mathrm{cm}) ; P$ is pressure at which flow rate is measured $(\mathrm{atm}) ; \bar{P}$ is average pressure inside the porous medium (atm); $\Delta P$ is the pressure difference across the sample length (atm) and $\eta$ is the viscosity of the flowing fluid (centipoises).

\section{Determination of Retention/Preservative Uptake}

Preservative uptake was used as an indicator of increasing the wood permeability for liquid. After microwave treatment all the treated samples along with controls were dipped for 6 hour in water soluble ACC (4\%) preservative. After treatment, excess preservative was blotted out with filter paper and specimens were weighed immediately to determine the preservative uptake and retention (IS 401:2001). Treated specimens were allowed to dry for 21 days for examining distribution and fixation of preservative and conditioning of specimens. The amount of preservative solution absorbed by specimen (retention value $\mathrm{R}$ in $\mathrm{Kg} \mathrm{m}^{-3}$ ) was calculated as (Tripathi 2012):

$$
R=\frac{G^{*} C^{*} 10}{V}
$$

Where, $\mathrm{G}$ is the weight of the preservative solution absorbed by the block $\left(\mathrm{W}_{2}-\mathrm{W}_{1}\right) \mathrm{kg}$. $\mathrm{C}$ is the weight in grams of the preservative in $100 \mathrm{~g}$ of treating solution and $\mathrm{V}$ is the volume of the test block in $\mathrm{m}^{3}$. 


\section{Measurement of Penetration}

The penetration of the preservative in each simple was determined by cross cutting the sample in the middle to expose a fresh cross section. The exposed surfaces were then sprayed with Chrome AzurolS solution to indicate the presence of copper. The wood turned blue where the ACC had penetrated, whereas the untreated zones were colored red. The area of the treated zone and its percentage on total cross section was calculated visually by measuring penetration of preservative in each specimen. The penetration data was analyzed as per IS 401:2001.

\section{Statistics}

Statistical analyses were conducted using SPSS 16 version software. Permeability and preservative uptake results of chir pine at different intensity and time were compared using variance analysis (ANOVA) and the Duncan homogeneity test at $95 \%$ confidence interval.

\section{RESULTS AND DISCUSSION}

\section{Longitudinal Air Permeability}

Although wood is a porous material with a variety of cylindrical pores in the fibre direction, the pit-aspirations in softwood or tyloses in hardwood result in poor inter-pore continuity and poor permeability of liquid or gas in wood (Kang et al. 2010). The effects of microwave treatment on the permeability to air in chir pine are shown in Table 1 . The study revealed that air permeability 5,51 Darcy was detected in the control or untreated specimens. The lower value of gas permeability can be attributed to saturation of free spaces with sap which hinders flow of air through wood. The reason for the low permeability may be due to the altered pit properties in heartwood and the extractives encrust the bordered pits and block the pits (Nicholas and Siau 1973). They reduced the diameter of the pit's pores and acted as glue connecting the torus to the side of the cavity. Another distribution possibility is the resin canals, as a network in longitudinal and radial directions. There are just a small number of resin canals and they may be closed by resins. So their importance for transporting liquids is generally limited (Cote 1963).

Statistical analysis revealed that there is a significant difference between the controls and treated specimens at different intensity and time levels. MW treatments T-1a and T-2a showed insignificant difference between them and T-1b, T-2b and T-3a treatments also showed insignificant but significantly different from other treatments for improvement in air permeability as well as preservative uptake. Among all the treatments, highest air permeability in longitudinal direction was observed in T-3b treatment i.e 14,39 Darcy (Table 1) which showed significant difference from other treatments.

Table 1. Mean value of air permeability and preservative uptake/ retention in P. roxburghii at different intensity and time of MW treatments.

\begin{tabular}{|c|c|c|c|c|}
\hline \multicolumn{2}{|c|}{ Intensity (W/cm $)$ and Time } & $\begin{array}{c}\text { Retention } \\
\left(\mathbf{k g} / \mathbf{m}^{3}\right)\end{array}$ & $\begin{array}{c}\text { Penetration of ACC } \\
\text { preservative (\%) }\end{array}$ & $\begin{array}{c}\text { Longitudinal } \\
\text { air } \\
\text { permeability } \\
(\text { Darcy) }\end{array}$ \\
\hline \multirow{2}{*}{$95,57 \mathrm{~W} / \mathrm{cm}^{2}(\mathrm{~T}-1)$} & $3 \mathrm{~min}(\mathrm{~T}-1 \mathrm{a})$ & $4,28^{\mathrm{a}}$ & $45^{\mathrm{e}}$ & $8,45^{\mathrm{i}}$ \\
\cline { 2 - 5 } & $5 \mathrm{~min}(\mathrm{~T}-1 \mathrm{~b})$ & $6,67^{\mathrm{b}}$ & $60^{\mathrm{f}}$ & $10,88^{\mathrm{j}}$ \\
\hline \multirow{2}{*}{$111,50 \mathrm{~W} / \mathrm{cm}^{2}(\mathrm{~T}-2)$} & $3 \mathrm{~min}(\mathrm{~T}-2 \mathrm{a})$ & $4,31^{\mathrm{a}}$ & $50^{\mathrm{e}}$ & $8,50^{\mathrm{i}}$ \\
\cline { 2 - 5 } & $5 \mathrm{~min}(\mathrm{~T}-2 \mathrm{~b})$ & $6,97^{\mathrm{b}}$ & $65^{\mathrm{f}}$ & $10,93^{\mathrm{j}}$ \\
\hline \multirow{2}{*}{$143,35 \mathrm{~W} / \mathrm{cm}^{2}(\mathrm{~T}-3)$} & $3 \mathrm{~min}(\mathrm{~T}-3 \mathrm{a})$ & $7,77^{\mathrm{b}}$ & $70^{\mathrm{f}}$ & $12,43^{\mathrm{j}}$ \\
\cline { 2 - 5 } & $5 \mathrm{~min}(\mathrm{~T}-3 \mathrm{~b})$ & $10,21^{\mathrm{c}}$ & $100^{\mathrm{g}}$ & $14,39^{\mathrm{k}}$ \\
\hline Control (C-1) & - & $1,96^{\mathrm{d}}$ & $15^{\mathrm{h}}$ & $5,51^{1}$ \\
\hline
\end{tabular}

Different letters denote significantly different groups. 
The permeability increased due to change in cell structure because of high pressure generated by steam within the wood. Under high internal steam pressure, the pit membranes in cell walls, tyloses in vessels, and the weak ray cells rupture to form pathways for easy transportation of liquids and vapours (Vinden et al. 2010). After wood microwave treatment, micro-checks were formed at the intercellular layer of ray cells, and the longitudinal tracheids and the pit membranes were damaged (He et al. 2014). These micro-checks might improve the air permeability of the treated wood. This reveals that MW treatment provides considerable permeability enhancement in P. roxburghii wood.

The results showed that MW treatment T-1a and T- 3 a resulted increase in permeability 8,45 and 12,43 Darcy respectively as compared to control i.e. 5,51 Darcy. There was slight increase in air permeability from 8,45 to 8,55 Darcy with increase in MW intensity from T-1a to T-2a and found insignificant difference between them (Table 1).

Air permeability showed significant difference i.e. 10,88 and 14,39 Darcy at T-1b and T-3b microwave treatment respectively (Table 1). The lower value of air permeability i.e 10,88 Darcy showed at T-1b and higher values i.e 14,39 Darcy at T-3b. Similar study of effect of microwave on wood permeability was also done by several scientists; Domeny et al. (2014) studied the effect of microwave radiation on the axial fluid permeability. Wang et al. (2014) reported that Microwave treatment (MW) improves the air permeability of Pinus sylvestris var. mongolica wood as micro-voids were formed in treated wood due to the destruction of the pit membranes, the wood ray cells, as well as the damage in the intercellular layer of the longitudinal tracheids.

\section{Preservative Impregnation}

The wood permeability depends on many factors such as the wood element distribution and the size of pits in the cell walls to the anatomical direction, density, moisture, etc. The penetration of any kinds of fluid into a porous media is directly related to its structure (Taghiyari, 2013); therefore, any small alterations in the porous structure by pressure or penetration of different liquid under pressure (Taghiyari 2012), heat (Ghorbani et al. 2012) or cold (Taghiyari et al. 2012), nanosilver-impregnation and intercropping of alfalfa would significantly change the permeation properties (Taghiyari 2014). Moreover, the retention/uptake of water-based preservatives (ACC) was used as an index of changing permeability after MW treatment. All the microwave treatments increased the preservative retention in the wood specimens as compared to control specimens is shown in table 1.

Mean retention of preservative is shown in Table 1. The result revealed that the control specimens showed only $1,96 \mathrm{~kg} / \mathrm{m}^{3}$ retention of preservative, after dip treatment for 6 hour. The results show that MW heating for 3 min followed by dipping in preservative resulted in 2 and 3 folds increase in retention $\left(4,27\right.$ and $\left.7,77 \mathrm{~kg} / \mathrm{m}^{3}\right)$ at T-1a and T-3a intensity level as compared to control. There was an increase in retention of preservative from 4,27 to $6,67 \mathrm{~kg} / \mathrm{m}^{3}$ with increase in MW treatment time from 3 to $5 \mathrm{~min}$ at T-1b intensity whereas, at T-3b the retention increased nearly 2 times $(7,77$ to $10,22 \mathrm{~kg} /$ $\mathrm{m}^{3}$ ) (Table 1). In comparison to control specimens the retention increased 3 and 5 folds respectively. 
Penetration of preservatives in different sections of wood is shown in (Table 1). The maximum penetration i.e. $100 \%$ was observed for at T-3b MW treatment whereas $15 \%$ penetration was found in control specimens. The results shown in table 1 that found a gradual improvement in penetration as increase treatment time and intensity. Thus result indicates that with increase in MW treatment time and intensity, wood permeability and retention/uptake were increased. This study is also support the result found in air permeability as well as preservative uptake. There was found a positive correlation i.e. $0,781^{* *}(\mathrm{P}<0,01)$ between air permeability and preservative impregnation after MW treatment improvement at different intensity and time. Similar result has also been reported by Treu \& Gjolsjo (2008) for Norway spruce (Picea abies). Terziev and Daniel (2013) also reported that the treated samples of Norway spruce (Picea abies) for improved wood permeability. Results shows that the water uptake of the treated samples was doubled compared to the untreated controls. An improved impregnation property of fir wood to acid copper chromate (ACC) with microwave pre treatment has been reported by Ramezanpour et al. (2014). He et al. (2014) studied the microwave (MW) treatment method was applied to Chinese fir wood to improve its liquid permeability.

\section{CONCLUSIONS}

The heartwood of chir pine treated with microwave at different intensity and time showed significant increase in permeability to air and preservative uptake. The results indicated that this technology can be tested and applied on pilot scale to find out if this method has potentiality in wood preservation industry for improvement of wood permeability and reducing the treatment time.

\section{ACKNOWLEDGEMENT}

The authors are thankful to Dr. P.P. Bhojvaid, Director Forest Research Institute, Dehradun, India, for providing facilities. The authors are also grateful to the staff of the Wood Preservation Discipline, F.R.I. Dehradun for providing necessary help during experimental work.

\section{REFERENCES}

Cote, W.A. 1963. Structural Factors Affecting the Permeability of Wood. Journal of Polymer Science 2: 231-242.

Dashti, H.; Tarmian, A.; Faezipour, M.; Hedjazi, S.; Shahverdi, M. 2012b. Effect of microwave radiation and pre-steaming treatments on the conventional drying characteristics of fir wood (Abies alba L.). Lignocellulose 1: 166-173.

Domeny, J.; Kois, V.; Dejmal, A. 2014. Permeability of false heartwood. BioResources 9(1): 372-380.

Fengel, D.; Wegener, G. 1984. Wood: chemistry, ultrastructure reactions. New York: Walter de Gruyter.

Ghorbani, M.; Akhtari, M.; Taghiyari, HR.; Kalantari, A. 2012. Effects of silver and zinc-oxide nanoparticles on gas and liquid permeability of heat treated Paulownia wood. Austrian Journal of Forest Science 129(2): 106-123.

Hansmann, C.; Wimmer, W.G.R.; Teischinger A. 2002. Permeability of wood - A review. Drevarsky Vyskum 47(4):1-16. 
He, S.; Lin, L.; Fu, F.; Zhou, Y.; Fan, M. 2014. Microwave treatment for enhancing the liquid permeability of Chinese fir. BioResources 9(2): 1924-1938.

IS:401. 2001. Preservation of timber-code of practice. Bureau of Indian standards. Manak Bhawan, New Delhi, India.

Kang, C.W.; Kim, G.C.; Park, H.J. 2010. Changes in permeability and sound absorption capability of yellow poplar wood by steam explosion treatment. Journal of the Faculty of Agriculture 55(2): 327-332.

Nicholas, D.D.; Siau, J.F. 1973. Factors influencing the treatability of wood. In: Nicholas, D.D. (ed.): Wood deterioration and its prevention by preservative treatments. II Preservatives and preservative systems. Syracuse Univ. Press, Syracuse, S. 299-343.

Panshin, A.J.; De Zeeuw, C. 1980. Textbook of Wood Technology: Structure, Identification, Properties and Uses of the Commercial Woods of the United States and Canada. McGraw-Hill Book Company. 722p.

Ramezanpour, M.; Tarmian, A.; Taghiyari, H.R. 2014. Improving impregnation properties of fir wood to acid copper chromate (ACC) with microwave pre-treatment. iForest (early view): e1-e6 [online 2014-04-01] URL: http://www.sisef.it/iforest/contents/?id=ifor1119-007.

Rajput, S.S.; Shukla, N.K.; Gupta, V.K.; Jain, J.D. 1996. Timber mechanics: Strenght, Classification and Grading of Timber. ICFRE, Deradun, India. 103pp.

Taghiyari, H.R. 2013. Effects of heat-treatment on permeability of untreated and nanosilver-impregnated native hardwoods. Maderas-Ciencia Tecnol 15(2): 183-194.

Taghiyari, H.R. 2014. Effects of nanosilver-impregnation and alfalfa-intercropping on fluid transfer in downy black poplar wood. Maderas-Cienc Tecnol 16(1):49-62.

Taghiyari, H.R. 2012. Correlation between gas and liquid permeabilities in some nanosilverimpregnated and untreated hardwoods. Journal of Tropical Forest Science 24 (2): 249-255.

Taghiyari, H.R.; Layeghi, M.; Aminzadeh Liyafooee, F. 2012. Effects of dry ice on gas permeability of nano-silver-impregnated Populus nigra and Fagus orientalis. IET Nanobiotechnology 6(2): 40-44.

Terziev, D. 2013. Application of high frequency treatments for improved permeability of Norway spruce (Picea abies Karst.) wood. In: Wood the BestMaterial for Mankind, Zvolen: Arbora Publishers, p.15-19.

Torgovnikov, G.; Vinden, P. 2009. High intensity microwave wood modification for increasing permeability. Forest Prod J 59(4): 84-92.

Treu, A.; Gjolsjo, S. 2008. Spruce impregnation, finally a breakthrough by means of microwave radiation In: Proceedings of the " $4^{\text {th }}$ Meeting of the Nordic Baltic Network in Wood Material Science \& Engineering (WSE)". Riga (Latvia) 13-14 Nov 2008. SNS-Nordic Forest Research Co-operation Committee, Copenhagen University, Horsholm, Denmark, pp. 42-48.

Tripathi, S. 2012. Treatability evaluation of meranti with ZiBOC and CCA. International Wood Products Journal 3: 70-76.

Vinden, P.; Torgovnikov, G.; Hann, J. 2010. Microwave modification of Radiata pine railway sleepers for preservative treatment. Eur. J. Wood Prod 69(2):271-279. 
Wang, D.; Peng, L.; Zhu, G.; Fu, F.; Zhou, Y.; Song, B. 2014. Sound absorption by wood. BioResources 9(4): 7504-7518.

Xu, K.; Wang, Y.; Lv, J.; Li, X.; Wu, Y. 2015. Microwaves \& wood impregnation. BioResources 10(1): 282-289. 